\title{
FAKTOR-FAKTOR PRODUKSI DAN KONSEP KEPEMILIKAN
}

\author{
(Kajian Pemikiran Abdul Mannan \\ Dalam "Islamic Economic Theory and Practice") \\ Oleh; Muhdi Kholil \\ (Dosen Ekonomi Syariah STIA Alma Ata Yogyakarta)
}

\begin{abstract}
Issues that are fundamentally appointed by Mannan in his book entitled: "Islamic Economic Theory and Practice" in the Islamic economic system in the theory or production concept is the principle of wealth. The concept of economic welfare in Islam consists of an increase in revenues that caused by increasing of production of good material through using resources maximally, both human and objects. Thus, the improvement of production system in Islam not only mean increased revenues that can only be measured in terms of money, but also improvements in the fulfillment of our needs maximally with minimal effort, but still consider the commandments of Islam in consumption.

When talking about the concept of ownership, Mannan had been taken ownership based on the Quran and As-Sunnah. In this case, Islam was different from capitalism and communism, because none of them was successful in placing individuals in a mosaic of social harmony. Private property is the foundation of capitalism. In other hand reducing of private property is its abolition is a target of socialist doctrine.
\end{abstract}

Key words: Mannan, Production, Ownership, Islam.

\section{A. PENDAHULUAN}

Kajian ini ditulis dengan tujuan untuk lebih mengerti dan memahami buku seorang ekonom Islam yaitu M. Abdul Mannan yang memberikan banyak inspirasi kepada kita tentang konsep-konsep dasar ekonomi Islam terutama tentang faktor-faktor produksi dan kepemilikan perspektif ekonomi Islam yang 
tertuang dalam bukunya dengan judul "Islamic Economic Theory and Practice”.

\section{B. PRINSIP PRODUKSI}

Sistem produksi dalam suatu negara Islam harus dikendalikan oleh kriteria obyektif maupun subyektif, kriteria obyektif akan tercermin dalam bentuk kesejahteraan yang dapat diukur dari segi uang. Sedangkan kriteria subyektifnya dapat dilihat dari segi etika ekonomi yang didasarkan atas perintah-perintah kitab suci Alqur'an dan Sunnah. Prinsip fundamental yang harus diperhatikan dalam proses produksi adalah prinsip kesejahteraan ekonomi.

Islam mengambil segala langkah yang masuk akal dalam mengurangi perbedaan pendapat akibat terpusatnya kekuasaan berproduksi dalam beberapa tangan saja. Hal ini diusahakan dengan beberapa cara diantaranya :

$\checkmark \quad$ Menjalankan sistem perpajakan progresif terhadap pendapatan

$\checkmark \quad$ Dikenakannya pajak warisan terhadap hak milik yang diwariskan denga perbandingan progresif

$\checkmark \quad$ Distribusi hasil pajak terutama yang terkumpul dari golongan-golongan yang lebih kaya, untuk masyarakat yang lebih miskin melalui pengaturan dinas-dinas sosial.

\section{FAKTOR-FAKTOR PRODUKSI}

Dalam Islam faktor produksi tidak hanya tunduk pada proses perubahan sejarah yang didesak oleh banyak kekuatan berlatar belakang penguangan (monetization) tenaga kerja, tanah dan modal, timbulnya negara nasional dari kerjaan feodal dan sebagainya, tetapi juga pada kerangka moraldan etika abadi sebagaimana tertulis dalam syariat. Adapun faktor-faktor produksi tersebut adalah: 


\section{Tanah}

Baik al-quran dan sunnah banyak memberikan tekanan pada pemnfaatan tanah secara baik, pemanfaatan dan pemeliharaan tanah sebagai suatu produksi juga dapat dianggap sebagai sumber alam dan dapat habis dalam kerangka suatu masyarakat ekonomi Islam. Pemborosan pemakaian tanah dalam bentuk apapun dikutuk, akan tetapi penggarapan tanah jangan merupakan satu-satunya pekerjaan dalam suatu negara Islam. Negara dapat mengadakan peraturan yang menjamin bahwa tanah sebagai faktor produksi digunakan sedemikian rupa sehingga dapat mencapai pertumbuhan berimbang bagi kepentingan masyarakat. Nabi berusaha mengingatkan para pengikutnya arti penting pembudidayaan tanah mereka, dan membuat ketentuan bahwa seorang hanya boleh memiliki tanah sebanyak yang dapat digarapnya sendiri.

Pembangunan pertanian pada negara-negara muslim dapat ditingkatkan melalui metode penanaman yang intensif dan ektensif jika dilengkapi dengan suatu program pendidikan moral, berdasarkan ajaran Islam. Penghasilan dari penggunaan sumber daya yang dapat habis harus digunakan untuk pembangunan lembaga-lembaga sosial (seperti uvinersitas, rumah sakit dll) dan untuk infra struktur fisik dari pada halhal yang bersifat konsumtif.

2. Tenaga kerja

Buruh merupakan faktor produksi yang diakui disetiap sitem ekonomi terlepas dari kecenderungan ideologi mereka.dalam Islam buruh bukan hanya suatu jumlah atau jasa abstrak yang ditawarkan untuk dijual pada para pencari tenaga kerja manusia. Mereka yang mempekerjakan buruh mempunyai tanggung jawab moral dan sosial. Dalam Islam buruh digunakan dalam arti yang lebih luas namun lebih terbatas. Lebih luas, karena hanya memandang pada penggunaan jasa buruh diluar batas-batas 
pertimbangan keuangan. Terbatas dalam arti bahwa seorang pekerja tidak secara mutlak bebas untuk berbuat apa saja yang dikehendakinya dengan tenaga kerjanya itu.

3. Modal

Suatu sistem ekonomi Islam harus bebas dari bunga. Dalam sistem itu bunga tidak diperkenankan memainkan pengaruhnya yang merugikan pekerja, produksi dan distribusi. Dengan alasan inilah modal menduduki tempat yang khusus dalam ilmu ekonomi Islam. Dalam hal ini kita cenderung menganggap modal "saran produksi yang menghasilkan" tidak sebagai faktor produksi pokok, melainkan sebagai suatu perwujudan tanah dan tenaga kerja sesudahnya. Pada kenyatannya modal dihasilkan oleh pemakaian tenaga kerja dan penggunaan sumber-sumber daya alam. Dalam Islam modal bukannyatanpa biaya, biaya modal dapat dinyatakan dari segi biaya peluang dalam kerangka Islami. Islam mengakui saham modal suatu saham yang bersifat berubah-ubah. Dengan demikian karena ada unsur keuntunganlah maka modal dapat tumbuh bahkan dalam perekonomian yang bebas bungan seperti Islam. Berbagai perintah alqur'an memberikan bukti bahwa Islam dapat memgkompromikan kedua pembentukan modal yang bertentangan yaitu konsumsi sekarang yang berkurang dan konsumsi masa depan yang bertambah, dengan demikian memungkinkan modal memainkan peranan yang sesungguhnya dalam proses produksi.

4. Organisasi

Organisasi muncul sebagai salah satu faktor produksi karena dianggap penting dalam sebuah analisis ekonomi terutama berhubungan dengan pengelolaan sumber daya manusia maupun bukan manusia. Untuk memahami ciri-ciri peranan organisasi dalam ekonomi Islam adalah : 
Pertama, dalam ekonomi Islam yang pada hakikatnya lebih berdasarkan ekuiti (equity-Based) daripada berdasarkan pinjaman ( LoanBased ). Kedua, sebagai akibatnya, pergertian tentang keuntungan biasa mempunyai arti yang lebih luas dalam kerangka ekonomi Islam karena bunga pada modal tidak dapat dikenakan lagi. Ketiga, karena sifat terpadu organisasi inilah tuntutan dan integritas moral, ketepatan dan kejujuran dalam perakuan (Accounting) barangkali jauh lebih diperlukan daripada organisasi sekular mana saja. Keempat, mempunyai signifikansi lebih diakui dibandingkan dengan strategi manajemen lainnyayang didasarkan pada memaksimalkan keuntungan atau penjualan.

\section{KONSEP HAK MILIK PRIBADI DALAM ISLAM}

Al-qur'an yang menjadi dasar semua hukum Islam, dengan tegas menyatakan bahwa konsep hak milik pribadi dalam Islam bersifat unik, dalam arti bahwa pemilik mutlak segala sesuatu yang ada di bumi dan di langit adalah Allah (Q.S.Ali Imran, 3: 189) manusia hanyalah kafilah Allah di muka bumi. Pada umumnya terdapat ketentuan syariat yang mengatur hak milik pribadi yaitu :

$\checkmark \quad$ Pemanfaatan harta benda secara terus menerus

$\checkmark \quad$ Pembayaran zakat sebanding dengan harat yang dimilki

$\checkmark \quad$ Penggunaan harta benta secara bermanfaat

$\checkmark \quad$ Penggunaan harta benda yang tidak merugikan orang lain.

$\checkmark \quad$ Memilki harta benda yang sah

$\checkmark \quad$ Penggunaan harta benda tidak dengan boros dan serakah

$\checkmark$ Penggunaan harta benda tidak dengan tujuan memperoleh keuntungan atas haknya

$\checkmark \quad$ Penerapan hukum waris yang tepat dalam Islam 
Kekhasan konsep Islam mengenai hak milik pribadi/individu terletak pada kenyataan bahwa dalam Islam legitimasi hak milik tergantung pada moral yang dikaitkan padanya.

\section{E. KESIMPULAN}

Abdul Mannan dalam buku yang berjudul:" Teori dan Praktek Ekonomi Islam.” membahas beberapa persoalan-persoalan yang secara fundamental diangkat oleh beliau baik dalam mekanisme yang ada dalam sistem ekonomi Islam maupun pada dataran teori atau konsep yang ada dalam sistem tersebut. Khusus pada bab ini akan dibahas mengenai konsep produksi dan kepemilikan dalam teori ekonomi Islam.

Prinsip fundamental yang harus selalu diperhatikan dalam proses produksi adalah prinsip kesejahteraan. Konsep kesejahteran ekonomi Islam terdiri dari bertambahnya pendapatan yang diakibatkan oleh meningkatnya produksi dari hanya barang-barang yang berfaedah melalui pemanfaatan sumber-sumber daya secara maksimum, baik manusia maupun benda demikian juga melalui ikut sertanya jumlah maksimum orang dalam proses produksi. Dengan demikian, perbaikan sitem produksi dalam Islam tidak hanya berarti meningkatkan pendapatan yang hanya dapat diukur dari segi uang, tetapi juga perbaikan dalam memaksimalkan terpenuhinya kebutuhan kita dengan usaha minimal tetapi tetap memperhatikan tuntunan perintah-perintah Islam tentang konsumsi.

Ketika berbicara mengenai konsep kepemilikan beliau menempatkan kepemilikan yang berdasarkan pada Al-qur'an dan As-sunnah. Dalam hal ini, lagi-lagi Islam berbeda dari kapitalisme dan komunisme, karena tidak satu pun dari keduaanya itu yang berhasil dalam menempatkan individu selaras dalam suatu mosaik sosial. Hak milik pribadi merupakan dasar kapitalisme, penghapusannya merupakan sasaran pokok ajaran sosialis. 


\section{DAFTAR PUSTAKA}

Mannan, M. Abdul, 1997, Teori dan Praktek Ekonomi Islam (Islamic Economic Theory and Practice), Yogyakarta: PT. Dana Bhakti Primayasa

An-Nabhani, Taqyuddin. (2002) Membangun Sistem Ekonomi Alternatif Perspekrif Islam, Surabaya: Risalah Gusti

Chapra, Muhammad Umer, 2001, Masa Depan Ilmu Ekonomi; Sebuah Tinjaun Islam, Cet. 1, Jakarta, Gema Insani Press bekerjasama dengan Tazkia Cendikia Naqvi, Haider. (2003) Menggagas Ilmu Ekonomi Islam, Yogyakarta: Pustaka Pelajar 